\title{
Serum aflatoxin levels of the healthy adult population living in the north and south regions of Turkey
}

\author{
Sevtap Aydin ${ }^{1}$, Suna Sabuncuoglu', Pinar Erkekoglu' ${ }^{1}$ Gönül Șahin ${ }^{2}$ and \\ Belma Kocer Giray ${ }^{1, *}$ \\ ${ }^{1}$ Faculty of Pharmacy, Department of Pharmaceutical Toxicology, Hacettepe University, 06100, Sihhiye, Ankara, \\ Turkey: ${ }^{2}$ Faculty of Pharmacy, Department of Pharmaceutical Toxicology, East Mediterranean University, \\ Famagusta, Turkish Republic of Northern Cyprus
}

Submitted 14 January 2013: Final revision received 19 August 2013: Accepted 20 August 2013: First published online 18 November 2013

\begin{abstract}
Objective: To determine the serum concentrations of aflatoxin $\mathrm{B}_{1}\left(\mathrm{AFB}_{1}\right)$, aflatoxin $B_{2}\left(A_{F}\right)$, aflatoxin $G_{1}\left(A_{F G}\right)$ and aflatoxin $G_{2}\left(A_{F} G_{2}\right)$ in the healthy adult population living in both the Black Sea and Mediterranean regions of Turkey and to investigate the regional, seasonal and gender variability in aflatoxins (AF) exposure in these regions.

Design: Serum $\mathrm{AFB}_{1}, \mathrm{AFB}_{2}, \mathrm{AFG}_{1}$ and $\mathrm{AFG}_{2}$ concentrations were analysed by HPLC.

Settings: In total, four hundred and eighty-four serum samples were analysed. Subjects: Four hundred and eighty-four healthy adult volunteers living in rural areas of the Black Sea and Mediterranean regions of Turkey were studied.

Results: The mean serum concentration of total AF in the Black Sea region was $1.33 \mathrm{ppb}(\min -\max 0 \cdot 15-3.38 \mathrm{ppb})$ and $0.90 \mathrm{ppb}(\min -\max 0 \cdot 18-2 \cdot 48 \mathrm{ppb})$ for summer and winter, respectively. In the Mediterranean region, the mean serum concentration of total $\mathrm{AF}$ was determined as $0.55 \mathrm{ppb}$ (range $0.04-1.72 \mathrm{ppb}$ ) for summer and $0.45 \mathrm{ppb}$ (range $0 \cdot 12-1.43 \mathrm{ppb}$ ) for winter. The total AF concentrations in serum samples were statistically higher in summer compared with winter for the two regions. The differences between the regions were statistically significant concerning all samples, with higher total AF concentrations in the Black Sea region.

Conclusions: The overall results suggest that the Turkish population living in these two regions is continuously exposed to AF, particularly in the summer, and that mycotoxin contamination in food should be monitored routinely for food safety and human health.
\end{abstract}

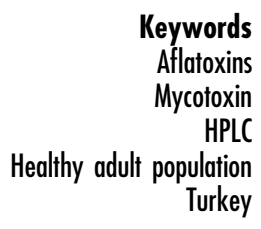

Aflatoxins (AF), first discovered in the 1960s, are naturally occurring contaminants of agricultural crops formed by several fungus species of the genus Aspergillus. Aspergillus flavus and Aspergillus parasiticus in particular are responsible for most AF contamination of food crops worldwide $^{(1)}$. The general population is exposed to AF primarily by consuming contaminated foods such as spices, dried fruits, cereals and cereal products. The four major types of $\mathrm{AF}$ are aflatoxin $\mathrm{B}_{1}\left(\mathrm{AFB}_{1}\right)$, aflatoxin $\mathrm{B}_{2}$ $\left(\mathrm{AFB}_{2}\right)$, aflatoxin $\mathrm{G}_{1}\left(\mathrm{AFG}_{1}\right)$ and aflatoxin $\mathrm{G}_{2}\left(\mathrm{AFG}_{2}\right)$. The relative proportions and amounts of the various $\mathrm{AF}$ on food crops depend on the Aspergillus species present, as well as on growing and storage conditions. Contamination is higher on crops grown in hot, humid and tropical climates generally, but also can occur in temperate climates varying from year to year. Pre-harvest AF levels increase during droughts, and post-harvest levels increase when crops are not properly dried before storage or are not protected from insect and rodent infestations. Rapid post-harvest drying and storage in an area with a moisture content of less than $10 \% \mathrm{w} / \mathrm{v}$ can eliminate most contamination $^{(1-4)}$.

$\mathrm{AF}$ are well-known human carcinogens based on sufficient evidence of carcinogenicity from studies in human subjects. $\mathrm{AFB}_{1}$ is one of the most potent carcinogens occurring naturally and is classified as a Group I carcinogen (carcinogenic to humans) by the International Agency for Research on Cancer ${ }^{(5)}$. This conclusion was reaffirmed in two subsequent re-evaluations ${ }^{(2,3)}$. The International Agency for Research on Cancer concluded that there was sufficient evidence in experimental animals for the carcinogenicity of naturally occurring mixtures of $\mathrm{AFB}_{1}, \mathrm{AFG}_{1}$ and $\mathrm{AFM}_{1}$; limited evidence for the carcinogenicity of $\mathrm{AFB}_{2}$; and inadequate evidence for the carcinogenicity of $\mathrm{AFG}_{2}$.

The primary target organ for AF toxicity and carcinogenicity is the liver in both man and animals. $\mathrm{AFB}_{1}$ is 
metabolized in the liver by the cytochrome $\mathrm{P} 450$ system to the highly reactive $\mathrm{AFB}_{1}-8,9$-epoxide, which is responsible for the toxicity ${ }^{(6-8)}$. The 8,9-epoxide metabolite can be detoxified through conjugation with glutathione, a reaction mediated by the enzyme glutathione $S$-transferase. The activity of glutathione $S$-transferase is much higher (by a factor of 3 to 5) in animal species that are resistant to $\mathrm{AF}$ carcinogenicity, such as the mouse, than in susceptible animal species, such as the rat. Man has a lower glutathione $S$-transferase activity than either the mouse or the rat, suggesting that people are less capable of detoxifying $\mathrm{AFB}_{1}$-8,9-epoxide. The metabolic effects of $\mathrm{AF}$ include inhibition of DNA, RNA and protein synthesis; reduction in miscellaneous enzyme activities; depression of glucose metabolism; inhibition of lipid synthesis, including that of phospholipids, NEFA, TAG and cholesterol and its esters; and depression of clotting factor synthesis ${ }^{(9)}$. The increased risk of hepatocarcinoma is caused by deletion mutations in the $p 53$ tumour-suppressing gene and by activation of dominant oncogenes ${ }^{(10)}$.

In 2002, the International Agency for Research on Cancer reported that experimental animals infected with hepatitis B virus (woodchucks, tree shrews and transgenic mice heterozygous for the $p 53$ tumour-suppressor gene) were more sensitive to the carcinogenic effects of AF than uninfected animals. On the other hand, epidemiological studies have also shown that AF exposure is associated with increased risk of hepatocellular carcinoma, particularly in combination with hepatitis B virus. The potency of AF appears to be significantly enhanced in individuals with hepatitis $\mathrm{B}$ infection ${ }^{(11-14)}$. The results of several cohort studies in China and Taiwan showed the association between biomarkers for AF exposure (AF metabolites in the urine and AF-albumin adducts in the blood) and primary liver-cell cancer and the association remained significant when the analyses were controlled for hepatitis $\mathrm{B}$ infection ${ }^{(5,15)}$. The correlation between dietary exposure to AF and the incidence of human liver cancer in some areas, especially in Africa and Asia, has been determined ${ }^{(16)}$. Due to the frequent occurrence of $\mathrm{AF}$ and their severe toxicity, guidelines and tolerance levels for AF have been set in several countries including Turkey ${ }^{(17,18)}$.

Turkey has encountered the AF contamination problem in different foods such as maize, nuts and hazelnuts exported and/or consumed in the country since $1967^{(19)}$. There are some studies on the levels of mycotoxins in different foods consumed and produced in Turkey, particularly on the concentrations of AF in cereals, cereal products, baby foods and infant formulas (20-25). However, AF levels in serum and urine of healthy people living in Turkey have not been assessed and there was no study on the evaluation of serum AF levels according to region, season and/or age. Therefore, the present study was undertaken to investigate the regional, seasonal and gender variability in AF exposure of the healthy adult population living in two different regions of Turkey by measuring serum AF concentrations by the HPLC technique.

\section{Materials and methods}

\section{Chemicals and reagents}

Methanol (MeOH) and acetonitrile (ACN) were HPLC grade and purchased from Riedel (Poole, Dorset, UK). Trifluoroacetic acid (TFA) was obtained from Sigma Chemical Co. (St. Louis, MO, USA). All other chemicals and solvents were purchased from Merck (Darmstadt, Germany).

\section{Standards}

$\mathrm{AF}$ standards $\left(\mathrm{AFG}_{1}, \mathrm{AFB}_{1}, \mathrm{AFG}_{2}\right.$ and $\left.\mathrm{AFB}_{2}\right)$ were obtained from Sigma Chemical Co. Stock solutions and standards were prepared and analysed according to AOAC Method $971 \cdot 22^{(26)}$.

\section{Participants}

The study was conducted in the rural areas of two provinces in the Black Sea (Ordu) and Mediterranean (Antalya) regions of Turkey. These regions have suitable hot, humid and tropical climatic conditions which favour the production of AF by Aspergillus species that contaminate many agricultural commodities during harvesting and/or while in storage. The sampling size for each province was selected by a web-based sampling program (RAOSOFT). The volunteers were chosen by the cluster sampling method. Our sample size represents the population with the margin of error as $5 \%$ and our confidence interval was $90 \%$. The blood samples were drawn from about twenty to twenty-five volunteers (who were living in that region for more than 5 years) from five villages of each province in health-care centres. In each village, there were about ten primary health-care centres. We randomly chose both the primary health-care centres (five centres for each village) and the healthy adult volunteers who applied to the health-care centres. Participants had no history of renal and hepatic disease. The numbers of female and male adult individuals were about the same in this sampling frame. The ages of the participants were between 17 and 64 years in the whole study group ( $n$ 484). In each cluster, the distributions of age and sex were normal. The weight and height of all participants were recorded, from which BMI ( = [body weight $(\mathrm{kg})] /[$ length $(\mathrm{m})]^{2}$ ) was calculated $^{(27)}$. Demographic information of the participants is presented in Table 1.

Dietary information, including the frequency of food intake, was collected through a standard FFQ administered face to face. The reference period for the FFQ was about 6 months. The eight food groups were red meat, white meat, fish, vegetable, fruit, milk and milk products, legumes, and corn and cereal products. The fasting blood samples were collected in the morning in July 2007 
(summer) and January 2008 (winter). The fasting blood samples were taken and the questionnaire was completed in $1 \mathrm{~h}$ before taking the fasting blood samples. The samples were centrifuged at $800 \mathrm{~g}$ for $15 \mathrm{~min}$ and the serum was separated. All serum samples were aliquoted and stored at $-20^{\circ} \mathrm{C}$ until analysis.

The study was approved by Hacettepe University Ethical Committee and conducted according to the Declaration of Helsinki. All individuals participated in the study voluntarily and written consent (in Turkish) was obtained before blood samples were drawn.

\section{Extraction of aflatoxins from serum samples}

After digestion of serum proteins ${ }^{(28,29)}$, the extraction method modified from Nelson et al. ${ }^{(30)}$ was performed. First, $1 \mathrm{ml}$ of serum sample was diluted with $2 \mathrm{ml}$ of n-hexane and mixed for $1 \mathrm{~min}$. After centrifugation at $5000 \mathrm{~g}$ for $5 \mathrm{~min}$, the upper n-hexane phase containing serum lipids was removed and discarded. This process was repeated for two more times. Next, $1 \mathrm{ml}$ of chloroform was added to the remaining part of the serum; the solution was shaken vigorously for $0.5 \mathrm{~min}$, vibrated for $4.5 \mathrm{~min}$ and centrifuged at $5000 \mathrm{~g}$ for $10 \mathrm{~min}$. The bottom chloroform layer was removed and transferred to a tube. This process was repeated for three more times. The chloroform phases collected in the tube were evaporated to complete dryness under a stream of nitrogen gas.

\section{Determination of aflatoxin levels by HPLC method}

The dry residue was derivatized with TFA according to the pre-column derivatization procedure of AOAC Method $971 \cdot 22^{(26)}$. Determination of $\mathrm{AFB}_{1}, \mathrm{AFB}_{2}, \mathrm{AFG}_{1}$ and $\mathrm{AFG}_{2}$ levels in the derivatized standards and samples was carried out by HPLC equipped with an auto sampler (Hewlett Packard Agilent 1100 Series, Vienna, Austria) using a fluorescence detector (excitation at $360 \mathrm{~nm}$, emission at $430 \mathrm{~nm}$ ). A Spherisorb S5ODS2 column $(3.8 \mathrm{~mm}$ i.d. and length $25 \mathrm{~cm}, 5 \mu \mathrm{m}$ particle size; Waters, Milford, MA, USA) was used. The mobile phase was deionized water-ACN-MeOH $(62: 16: 22, \mathrm{v} / \mathrm{v} / \mathrm{v})$ and the flow rate was $1 \mathrm{ml} / \mathrm{min}$. The injection volume was $100 \mu \mathrm{l}$. The AF standards used ranged between 5 and $1000 \mathrm{pg} / \mathrm{ml}$. The retention times were $6 \cdot 2 \mathrm{~min}$ for $\mathrm{AFG}_{1}, 8 \cdot 2 \mathrm{~min}$ for $\mathrm{AFB}_{1}, 11 \cdot 8 \mathrm{~min}$ for $\mathrm{AFG}_{2}$ and $17 \cdot 0 \mathrm{~min}$ for $\mathrm{AFB}_{2}$. Recovery studies were performed on blank samples of serum spiked with levels of $0 \cdot 1 \mathrm{ng} / \mathrm{ml}, 0 \cdot 25 \mathrm{ng} / \mathrm{ml}$ and $0.5 \mathrm{ng} / \mathrm{ml}$ for each AF standard and repeated for three times. The average recoveries were $69.7 \%$ for $\mathrm{AFG}_{1}, 79.6 \%$ for $\mathrm{AFB}_{1}, 101 \cdot 3 \%$ for $\mathrm{AFG}_{2}$ and $107 \cdot 4 \%$ for $\mathrm{AFB}_{2}$. The concentrations of $\mathrm{AF}$ in the samples were calculated by using the calibration curves of peak area prepared for each AF standard separately. The detection and quantification limits of the analyses were calculated according to the method of the US Environmental Protection Agency ${ }^{(31)}$. The detection limits were determined as $25 \mathrm{pg} / \mathrm{ml}$ for $\mathrm{AFG}_{1}$ and $\mathrm{AFB}_{1}, 10 \mathrm{pg} / \mathrm{ml}$ for $\mathrm{AFG}_{2}$ and $20 \mathrm{pg} / \mathrm{ml}$ for $\mathrm{AFB}_{2}$.
The quantification limits were determined as $176 \mathrm{pg} / \mathrm{ml}$ for $\mathrm{AFG}_{1}, 106 \mathrm{pg} / \mathrm{ml}$ for $\mathrm{AFB}_{1}, 242 \mathrm{pg} / \mathrm{ml}$ for $\mathrm{AFG}_{2}$ and $139 \cdot 4 \mathrm{pg} / \mathrm{ml}$ for $\mathrm{AFB}_{2}$.

\section{Statistical analysis}

The results were expressed as means and standard deviations. The distribution of the data was checked for normality using the Shapiro-Wilk test. The homogeneity of the variance was verified by the Levene test. The association between the rankings of two variables was measured by Spearman's rank correlation. The differences among the groups were evaluated with the Mann-Whitney $U$ test using the statistical software package IBM SPSS version $17 \cdot 0$. For dependent variables, the Wilcoxon signed-rank test was also performed (data not shown). $P$ values $<0 \cdot 05$ were considered as statistically significant.

\section{Results}

\section{Participants' characteristics}

The total of 484 blood samples were collected from healthy adults living in the Black Sea and Mediterranean regions of Turkey in the period 2007-2008 and analysed for $\mathrm{AFB}_{1}, \mathrm{AFB}_{2}, \mathrm{AFG}_{1}$ and $\mathrm{AFG}_{2}$ by the HPLC technique. The number of the samples collected in summer and winter periods in both regions and the distribution according to gender are given in Table 1 . In the Black Sea region, 104 matched samples were obtained for the two seasons; six samples in summer and nine samples in winter were collected from different persons. The mean age was 39.0 (SD 11.7) years (min-max 19-64 years) and the mean BMI was 26.5 (sD $4 \cdot 3$ ) $\mathrm{kg} / \mathrm{m}^{2}$ (min-max $18 \cdot 6-39 \cdot 1 \mathrm{~kg} / \mathrm{m}^{2}$ ). In the Mediterranean region, $126 \mathrm{sam}-$ ples were from the same persons for the two seasons; nine more samples were obtained in the winter period. The mean age was $42 \cdot 2$ (SD $12 \cdot 5)$ years (min-max $17-64$ years) and the mean BMI was $27 \cdot 5$ (SD 5.2) $\mathrm{kg} / \mathrm{m}^{2}$ $\left(\min -\max 15 \cdot 6-53 \cdot 6 \mathrm{~kg} / \mathrm{m}^{2}\right)$.

According to answers obtained from the FFQ, the dietary habits of the inhabitants in the two regions were not same completely. Although the populations in these regions consume vegetables, fruits and meat as well as locally produced food, the people living in the Black Sea region consumed more cereals including corn and corn products, whereas the consumption of fruit and vegetables was higher in the Mediterranean region.

\section{Evaluation of serum aflatoxin levels}

In the Black Sea region, $\mathrm{AFB}_{1}$ levels were detectable in $90.0 \%$ of all samples collected in the summer and in $81 \cdot 4 \%$ of the winter samples. The percentages of positive samples were $86 \cdot 4 \%$ for $\mathrm{AFG}_{1}$ and $\mathrm{AFG}_{2}$ and $65 \cdot 5 \%$ for $\mathrm{AFB}_{2}$ in the summer period. In the winter, the percentages of positive samples were found to be $85.5 \%$ for $\mathrm{AFG}_{1}, 80 \cdot 5 \%$ for $\mathrm{AFG}_{2}$ and $43 \cdot 4 \%$ for $\mathrm{AFB}_{2}$ (Table 2 ). 
Table 1 Demographic characteristics of the study population according to region, season and gender: healthy adults living in rural areas of the Black Sea region and the Mediterranean region of Turkey, 2007-2008

\begin{tabular}{|c|c|c|c|c|c|c|c|c|c|c|c|c|c|c|}
\hline & \multirow[b]{2}{*}{ Sex } & \multirow[b]{2}{*}{$n$} & \multicolumn{3}{|c|}{ Age (years) } & \multicolumn{3}{|c|}{ Height $(\mathrm{cm})$} & \multicolumn{3}{|c|}{ Body weight $(\mathrm{kg})$} & \multicolumn{3}{|c|}{ BMI $\left(\mathrm{kg} / \mathrm{m}^{2}\right)$} \\
\hline & & & Mean & SD & Min-max & Mean & SD & Min-max & Mean & SD & Min-max & Mean & SD & Min-max \\
\hline \multicolumn{15}{|l|}{ Black Sea region } \\
\hline \multirow[t]{3}{*}{ Summer } & Female & 56 & $39 \cdot 8$ & $12 \cdot 0$ & $19-62$ & $160 \cdot 6$ & $5 \cdot 7$ & $148-174$ & $66 \cdot 4$ & $10 \cdot 5$ & $49-90$ & $25 \cdot 8$ & $4 \cdot 4$ & $18 \cdot 6-37 \cdot 9$ \\
\hline & Male & 54 & $41 \cdot 1$ & $12 \cdot 3$ & $22-64$ & $171 \cdot 2$ & $6 \cdot 1$ & $158-183$ & $80 \cdot 0$ & $11 \cdot 8$ & $56-105$ & $27 \cdot 3$ & $3 \cdot 8$ & $19 \cdot 4-34 \cdot \varepsilon$ \\
\hline & Overall & 110 & $40 \cdot 5$ & $12 \cdot 1$ & $19-64$ & $165 \cdot 8$ & $7 \cdot 9$ & $148-183$ & $73 \cdot 1$ & $13 \cdot 1$ & $49-105$ & $26 \cdot 5$ & $4 \cdot 1$ & $18 \cdot 6-37 \cdot 9$ \\
\hline \multirow[t]{4}{*}{ Winter } & Female & 56 & $37 \cdot 7$ & $11 \cdot 0$ & $19-62$ & $160 \cdot 3$ & $6 \cdot 1$ & $148-175$ & $66 \cdot 3$ & $12 \cdot 2$ & $48-100$ & $25 \cdot 8$ & $4 \cdot 8$ & $18 \cdot 6-39 \cdot 1$ \\
\hline & Male & 57 & $37 \cdot 1$ & $10 \cdot 9$ & $19-64$ & $171 \cdot 5$ & $6 \cdot 2$ & $160-185$ & $79 \cdot 1$ & $11 \cdot 6$ & $56-105$ & $26 \cdot 8$ & $3 \cdot 8$ & $19 \cdot 4-35 \cdot 5$ \\
\hline & Overall & 113 & $37 \cdot 6$ & $11 \cdot 1$ & $19-62$ & $166 \cdot 1$ & $8 \cdot 4$ & $148-185$ & $73 \cdot 0$ & $13 \cdot 8$ & $48-105$ & $26 \cdot 4$ & $4 \cdot 4$ & $18 \cdot 6-39 \cdot 1$ \\
\hline & \multicolumn{14}{|c|}{ Mediterranean region } \\
\hline \multirow[t]{3}{*}{ Summer } & Female & 88 & $40 \cdot 5$ & $12 \cdot 5$ & $17-64$ & $159 \cdot 7$ & $5 \cdot 5$ & $150-170$ & $69 \cdot 7$ & $13 \cdot 0$ & $48-120$ & $27 \cdot 4$ & $5 \cdot 3$ & $15 \cdot 9-35 \cdot 3$ \\
\hline & Male & 38 & $44 \cdot 0$ & $12 \cdot 9$ & $17-63$ & $169 \cdot 7$ & $7 \cdot 0$ & $150-184$ & $78 \cdot 4$ & $12 \cdot 6$ & $54-108$ & $27 \cdot 3$ & $4 \cdot 3$ & $20 \cdot 3-35 \cdot 2$ \\
\hline & Overall & 126 & $41 \cdot 5$ & $12 \cdot 7$ & $17-64$ & $162 \cdot 7$ & $7 \cdot 5$ & $150-184$ & $72 \cdot 3$ & $13 \cdot 5$ & $48-120$ & $27 \cdot 3$ & $5 \cdot 0$ & $15 \cdot 9-35 \cdot 3$ \\
\hline \multirow[t]{3}{*}{ Winter } & Female & 86 & $40 \cdot 5$ & $11 \cdot 9$ & $17-63$ & $159 \cdot 7$ & $6 \cdot 6$ & $133-170$ & $70 \cdot 2$ & $14 \cdot 1$ & $30-120$ & $27 \cdot 6$ & $5 \cdot 8$ & $15 \cdot 6-53 \cdot 6$ \\
\hline & Male & 49 & $46 \cdot 5$ & $13 \cdot 0$ & $17-63$ & $168 \cdot 5$ & $6 \cdot 2$ & $150-183$ & $78 \cdot 5$ & $14 \cdot 0$ & $49-115$ & $27 \cdot 7$ & 4.9 & $16 \cdot 0-42 \cdot 2$ \\
\hline & Overall & 135 & $42 \cdot 7$ & $12 \cdot 6$ & $17-63$ & $162 \cdot 9$ & $7 \cdot 7$ & $133-183$ & $73 \cdot 2$ & $14 \cdot 6$ & $30-120$ & $27 \cdot 6$ & $5 \cdot 4$ & $15 \cdot 6-53 \cdot 6$ \\
\hline
\end{tabular}

Table 2 Numbers and percentages of aflatoxin-positive* samples in the study population according to region, season and gender: healthy adults living in rural areas of the Black Sea region and the Mediterranean region of Turkey, 2007-2008

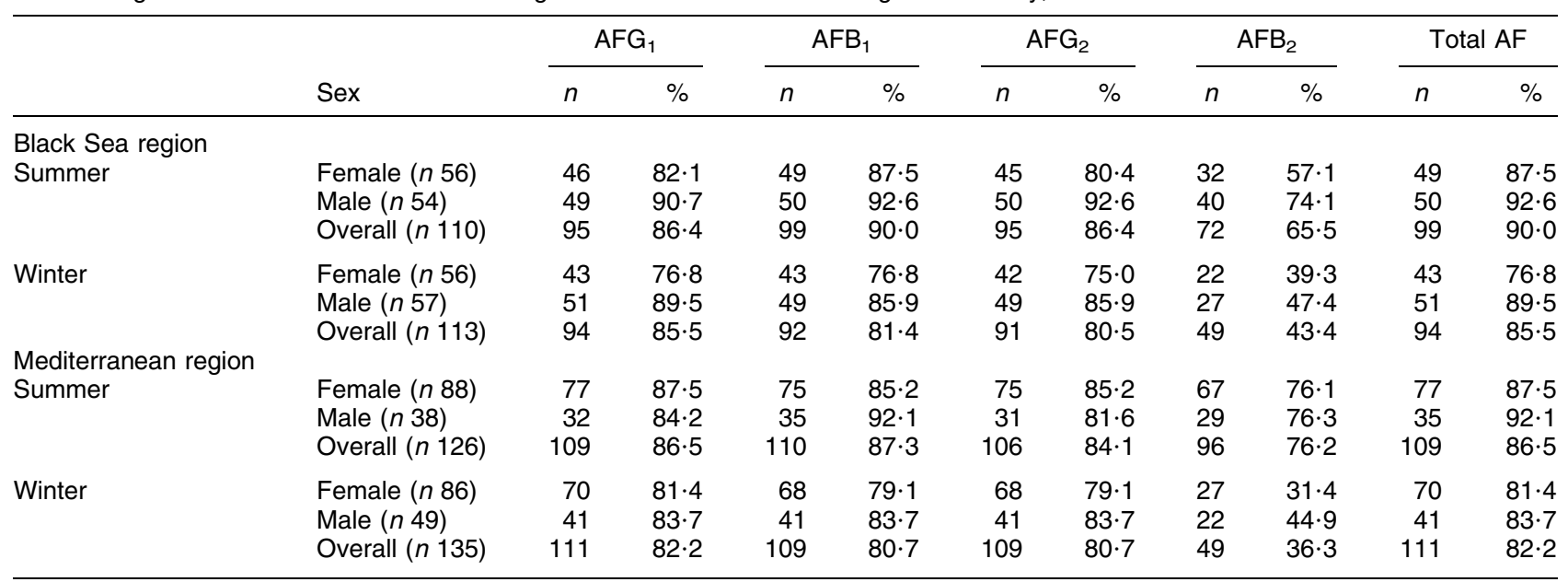

$A F G_{1}$, aflatoxin $G_{1} ; A F B_{1}$, aflatoxin $B_{1} ; A F G_{2}$, aflatoxin $G_{2} ; A F B_{2}$, aflatoxin $B_{2}$; total $A F$, total aflatoxins.

${ }^{*}$ Positive samples were those with detectable levels $\left(>25 \mathrm{pg} / \mathrm{ml}\right.$ for $A F G_{1}$ and $A F B_{1} ;>10 \mathrm{pg} / \mathrm{ml}$ and $20 \mathrm{pg} / \mathrm{ml}$ for $A F G_{2}$ and $A F B_{2}$, respectively).

In the Mediterranean region, the distribution of positive samples collected in both seasons was similar to that in the Black Sea region. The percentages of positive samples collected in the summer were $86 \cdot 5 \%$ for $\mathrm{AFG}_{1}, 87 \cdot 3 \%$ for $\mathrm{AFB}_{1}, 84 \cdot 1 \%$ for $\mathrm{AFG}_{2}$ and $76 \cdot 2 \%$ for $\mathrm{AFB}_{2}$. In the winter $82 \cdot 2 \%, 80 \cdot 7 \%, 80 \cdot 7 \%$ and $36 \cdot 3 \%$ of the samples contained detectable levels of $\mathrm{AFG}_{1}, \mathrm{AFB}_{1}, \mathrm{AFG}_{2}$ and $\mathrm{AFB}_{2}$, respectively (Table 2 ).

The mean serum concentration of total AF determined in all samples in the present study was $1 \cdot 12 \mathrm{ppb}$ (min-max $0.15-3.38 \mathrm{ppb}$ ) and $0.50 \mathrm{ppb}$ (min-max 0.04-1.72 ppb) for the Black Sea and Mediterranean regions of Turkey, respectively.

The mean serum AF concentrations detected in all samples according to gender, season and region are summarized in Tables 3 and 4. In the Black Sea region, we did not observe any significant differences in $\mathrm{AF}$ levels between the sexes, except for $\mathrm{AFB}_{2}$. Females had significantly higher $\mathrm{AFB}_{2}$ levels than males only in winter $(P<0 \cdot 05$; Table 3$)$. However, $\mathrm{AFB}_{1}, \mathrm{AFB}_{2}$ and total $\mathrm{AF}$ levels were found to be significantly higher in summer samples of females than males in the Mediterranean region. In winter, there was not any significant difference in all AF levels measured between males and females (Table 4).

$\mathrm{AFG}_{1}, \mathrm{AFB}_{1}, \mathrm{AFG}_{2}$ and total $\mathrm{AF}$ levels in the Black Sea population ( $n$ 110) were significantly higher than those in the Mediterranean population in the summer period (Fig. 1). The mean serum concentration of total AF in the Black Sea region was $1.33 \mathrm{ppb}(\min -\max 0 \cdot 15-3 \cdot 38 \mathrm{ppb})$ and $0.90 \mathrm{ppb}$ (min-max $0 \cdot 18-2 \cdot 48 \mathrm{ppb})$ for summer and winter, respectively. In the Mediterranean region, the mean serum concentration of total AF was $0.55 \mathrm{ppb}$ (min-max $0.04-1.72 \mathrm{ppb}$ ) for summer and $0.45 \mathrm{ppb}$ (min-max $0 \cdot 12-1 \cdot 43 \mathrm{ppb})$ for winter. In winter, $\mathrm{AFG}_{1}$, $\mathrm{AFB}_{1}, \mathrm{AFG}_{2}, \mathrm{AFB}_{2}$ and total $\mathrm{AF}$ levels were found to be 
Table 3 Serum aflatoxin levels of the study population according to season and gender: healthy adults living in rural areas of the Black Sea region of Turkey, 2007-2008

\begin{tabular}{|c|c|c|c|c|c|c|c|c|c|c|c|c|c|c|c|c|c|}
\hline \multirow[b]{2}{*}{ Season } & \multirow[b]{2}{*}{ Sex } & \multirow[b]{2}{*}{$n$} & \multicolumn{3}{|c|}{$\mathrm{AFG}_{1}(\mathrm{ppb})$} & \multicolumn{3}{|c|}{$\mathrm{AFB}_{1}(\mathrm{ppb})$} & \multicolumn{3}{|c|}{$\mathrm{AFG}_{2}(\mathrm{ppb})$} & \multicolumn{3}{|c|}{$\mathrm{AFB}_{2}(\mathrm{ppb})$} & \multicolumn{3}{|c|}{ Total AF (ppb) } \\
\hline & & & Mean & SD & Min-max & Mean & SD & Min-max & Mean & SD & Min-max & Mean & SD & Min-max & Mean & SD & Min-max \\
\hline Summer & $\begin{array}{l}\text { Female } \\
\text { Male }\end{array}$ & $\begin{array}{l}56 \\
54\end{array}$ & $\begin{array}{l}0.225^{a} \\
0.223^{a}\end{array}$ & $\begin{array}{l}0.120 \\
0.179\end{array}$ & $\begin{array}{l}0.038-0.619 \\
0.063-1.241\end{array}$ & $\begin{array}{l}0.885^{\mathrm{a}} \\
0.800^{\mathrm{a}}\end{array}$ & $\begin{array}{l}0.418 \\
0.466\end{array}$ & $\begin{array}{l}0.232-2.066 \\
0.125-1.913\end{array}$ & $\begin{array}{l}0.247^{\mathrm{a}} \\
0.207^{\mathrm{a}}\end{array}$ & $\begin{array}{l}0 \cdot 178 \\
0 \cdot 166\end{array}$ & $\begin{array}{l}0.010-0.858 \\
0.020-1.036\end{array}$ & $\begin{array}{l}0 \cdot 136^{\mathrm{a}} \\
0 \cdot 106^{\mathrm{a}}\end{array}$ & $\begin{array}{l}0.096 \\
0.087\end{array}$ & $\begin{array}{l}0.020-0.474 \\
0.022-0.541\end{array}$ & $\begin{array}{l}1 \cdot 371^{\mathrm{a}} \\
1 \cdot 288^{\mathrm{a}}\end{array}$ & $\begin{array}{l}0.665 \\
0.685\end{array}$ & $\begin{array}{l}0 \cdot 149-2 \cdot 979 \\
0 \cdot 209-3 \cdot 384\end{array}$ \\
\hline Winter & $\begin{array}{l}\text { Female } \\
\text { Male }\end{array}$ & $\begin{array}{l}56 \\
57\end{array}$ & $\begin{array}{l}0 \cdot 145^{b} \\
0 \cdot 126^{b}\end{array}$ & $\begin{array}{l}0.111 \\
0.066\end{array}$ & $\begin{array}{l}0.033-0.588 \\
0.030-0.286\end{array}$ & $\begin{array}{l}0.513^{b} \\
0.521^{b}\end{array}$ & $\begin{array}{l}0.393 \\
0.363\end{array}$ & $\begin{array}{l}0.112-2 \cdot 185 \\
0.116-2 \cdot 297\end{array}$ & $\begin{array}{l}0.209^{a} \\
0 \cdot 234^{a}\end{array}$ & $\begin{array}{l}0.071 \\
0.083\end{array}$ & $\begin{array}{l}0.065-0.363 \\
0.059-0.478\end{array}$ & $\begin{array}{l}0 \cdot 111^{a} \\
0 \cdot 069^{b}\end{array}$ & $\begin{array}{l}0.136 \\
0.045\end{array}$ & $\begin{array}{l}0.018-0.676 \\
0.020-0.191\end{array}$ & $\begin{array}{l}0.899^{b} \\
0.904^{b}\end{array}$ & $\begin{array}{l}0.513 \\
0.474\end{array}$ & $\begin{array}{l}0.177-2 \cdot 347 \\
0.186-2 \cdot 482\end{array}$ \\
\hline
\end{tabular}

$A F G_{1}$, aflatoxin $G_{1} ; A F B_{1}$, aflatoxin $B_{1} ; A F G_{2}$, aflatoxin $G_{2} ; A F B_{2}$, aflatoxin $B_{2} ;$ total $A F$, total aflatoxins.

${ }^{a, b}$ Mean values within a column with unlike superscript letters were significantly different $(P<0 \cdot 05)$.

Table 4 Serum aflatoxin levels of the study population according to season and gender: healthy adults living in rural areas of the Mediterranean region of Turkey, 2007-2008

\begin{tabular}{|c|c|c|c|c|c|c|c|c|c|c|c|c|c|c|c|c|c|}
\hline \multirow[b]{2}{*}{ Season } & \multirow[b]{2}{*}{ Sex } & \multirow[b]{2}{*}{$n$} & \multicolumn{3}{|c|}{$\mathrm{AFG}_{1}(\mathrm{ppb})$} & \multicolumn{3}{|c|}{$\mathrm{AFB}_{1}(\mathrm{ppb})$} & \multicolumn{3}{|c|}{$\mathrm{AFG}_{2}(\mathrm{ppb})$} & \multicolumn{3}{|c|}{$\mathrm{AFB}_{2}(\mathrm{ppb})$} & \multicolumn{3}{|c|}{ Total AF (ppb) } \\
\hline & & & Mean & SD & Min-max & Mean & SD & Min-max & Mean & SD & Min-max & Mean & SD & Min-max & Mean & SD & Min-max \\
\hline Summer & $\begin{array}{l}\text { Female } \\
\text { Male }\end{array}$ & $\begin{array}{l}88 \\
38\end{array}$ & $\begin{array}{l}0 \cdot 131^{a} \\
0 \cdot 101^{a}\end{array}$ & $\begin{array}{l}0.064 \\
0.061\end{array}$ & $\begin{array}{l}0.038-0.289 \\
0.033-0.341\end{array}$ & $\begin{array}{l}0.235^{a} \\
0.185^{b}\end{array}$ & $\begin{array}{l}0.153 \\
0.087\end{array}$ & $\begin{array}{l}0.040-1.130 \\
0.060-0.556\end{array}$ & $\begin{array}{l}0 \cdot 161^{\mathrm{a}} \\
0 \cdot 156^{\mathrm{a}}\end{array}$ & $\begin{array}{l}0.058 \\
0.044\end{array}$ & $\begin{array}{l}0.054-0.446 \\
0.017-0.222\end{array}$ & $\begin{array}{l}0.099^{\mathrm{a}} \\
0.074^{\mathrm{b}}\end{array}$ & $\begin{array}{l}0.055 \\
0.047\end{array}$ & $\begin{array}{l}0.023-0.233 \\
0.026-0.238\end{array}$ & $\begin{array}{l}0.581^{a} \\
0.469^{b}\end{array}$ & $\begin{array}{l}0.295 \\
0.227\end{array}$ & $\begin{array}{l}0.038-1.719 \\
0.040-1.322\end{array}$ \\
\hline Winter & $\begin{array}{l}\text { Female } \\
\text { Male }\end{array}$ & $\begin{array}{l}86 \\
49\end{array}$ & $\begin{array}{l}0.075^{\mathrm{a}} \\
0.062^{\mathrm{a}}\end{array}$ & $\begin{array}{l}0.103 \\
0.053\end{array}$ & $\begin{array}{l}0.032-0.627 \\
0.032-0.332\end{array}$ & $\begin{array}{l}0 \cdot 189^{b} \\
0 \cdot 193^{b}\end{array}$ & $\begin{array}{l}0.123 \\
0.105\end{array}$ & $\begin{array}{l}0.055-0.862 \\
0.041-0.531\end{array}$ & $\begin{array}{l}0 \cdot 177^{\mathrm{a}} \\
0 \cdot 166^{\mathrm{a}}\end{array}$ & $\begin{array}{l}0.066 \\
0.051\end{array}$ & $\begin{array}{l}0.068-0.410 \\
0.043-0.323\end{array}$ & $\begin{array}{l}0.034^{\mathrm{c}} \\
0.053^{\mathrm{c}}\end{array}$ & $\begin{array}{l}0.009 \\
0.068\end{array}$ & $\begin{array}{l}0.020-0.055 \\
0.021-0.306\end{array}$ & $\begin{array}{l}0 \cdot 448^{b} \\
0 \cdot 449^{b}\end{array}$ & $\begin{array}{l}0.203 \\
0.156\end{array}$ & $\begin{array}{l}0.121-1.430 \\
0.194-0.921\end{array}$ \\
\hline
\end{tabular}

$A F G_{1}$, aflatoxin $G_{1} ; A F B_{1}$, aflatoxin $B_{1} ; A F G_{2}$, aflatoxin $G_{2} ; A F B_{2}$, aflatoxin $B_{2} ;$ total $A F$, total aflatoxins.
a,b,c Mean values within a column with unlike superscript letters were significantly different $(P<0 \cdot 05)$. 

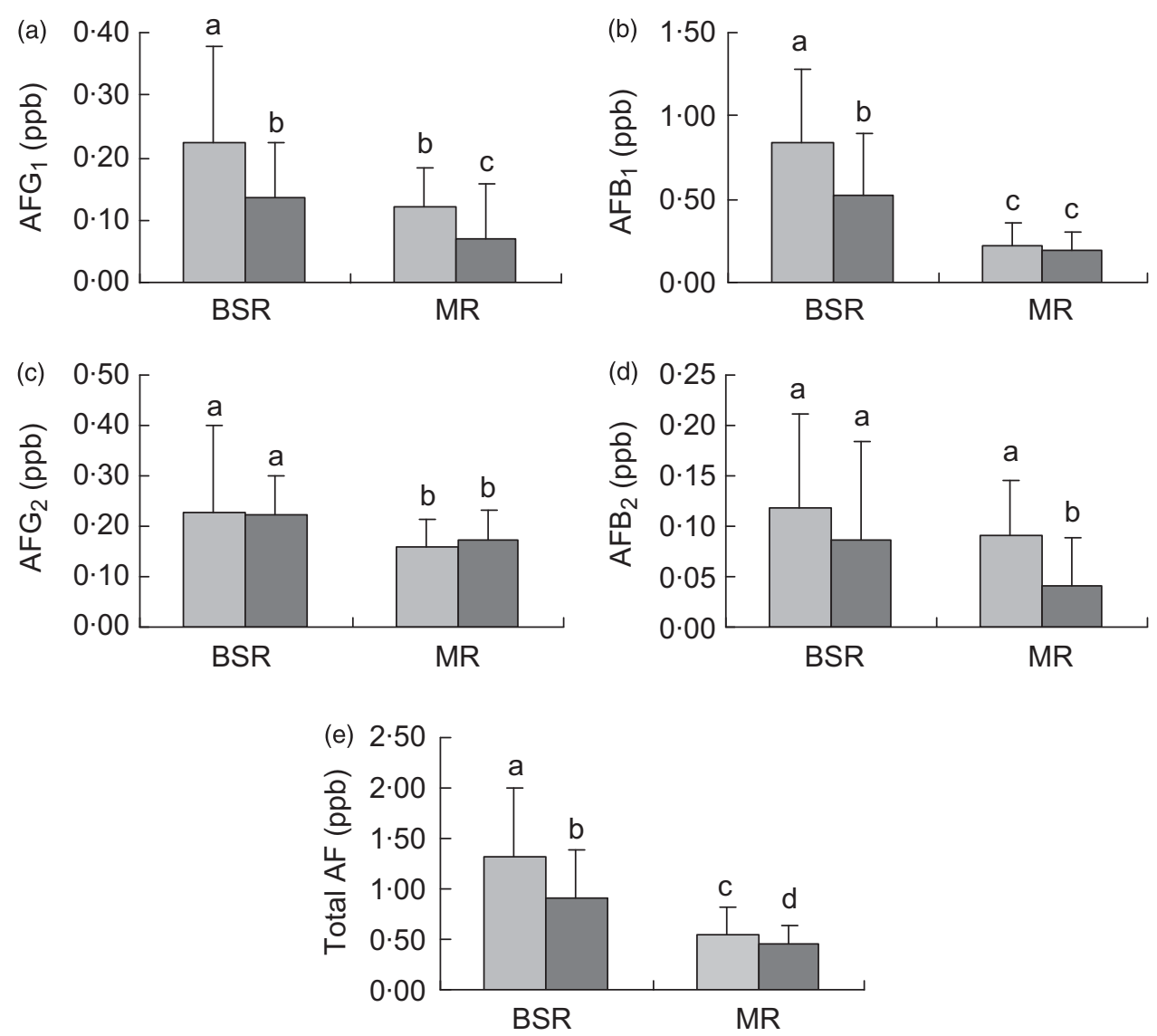

Fig. 1 Serum aflatoxin levels in the healthy adult population living in rural areas of the Black Sea region (BSR) and the Mediterranean region (MR) of Turkey according to season ( $\square$, summer (July 2007); $\square$, winter (January 2008)): (a) aflatoxin $G_{1}$ $\left(A F G_{1}\right)$; (b) aflatoxin $B_{1}\left(A F B_{1}\right)$; (c) aflatoxin $G_{2}\left(A F G_{2}\right)$; (d) aflatoxin $B_{2}\left(A F B_{2}\right)$; (e) total aflatoxins (total $\left.A F\right)$. Values are means with their standard deviations represented by vertical bars; BSR: $n 110$ for summer, $n 113$ for winter; MR: $n 126$ for summer, $n 135$ for winter. ${ }^{a, b, c, d}$ Mean values with unlike superscript letters were significantly different $(P<0.05)$

higher in Black Sea samples compared with Mediterranean samples (Fig. 1). $\mathrm{AFG}_{1}, \mathrm{AFB}_{1}$ and total $\mathrm{AF}$ levels in the Black Sea region and $\mathrm{AFG}_{1}, \mathrm{AFB}_{2}$ and total $\mathrm{AF}$ levels in the Mediterranean region were higher in summer compared with winter (Fig. 1). The highest $\mathrm{AFB}_{2}$ and $\mathrm{AFG}_{2}$ levels were also seen in the summer samples collected from the Black Sea region, but no significant differences were observed due to the high standard deviation. The lowest AF levels were measured in the winter samples from the Mediterranean region (Fig. 1). Total AF levels were $32 \%$ and $18 \%$ lower in winter samples compared with summer samples in the Black Sea and Mediterranean regions, respectively.

There was no correlation and relationship between the dependent variables (the levels of $\mathrm{AF}$ ) and independent variables (age and BMI).

\section{Discussion}

The contamination of crops with mycotoxins is a major determinant of trade for all economies. Major risks are inevitable climatic conditions such as unseasonable rains or high humidity ${ }^{(3)}$. The possible role of AF in influencing human health has been researched mainly in relation to their role as a carcinogen. It is well documented that contamination of foods with AF may cause liver cancer in $\operatorname{man}^{(14,16)}$. However, AF also have a major effect on the immune system and these toxins may also affect the epidemiology of many diseases and health risks in those countries where the toxin is uncontrolled ${ }^{(8)}$. A nonharmful level of AF has not yet been identified.

There are a few studies in the literature demonstrating $\mathrm{AF}$ levels in serum ${ }^{(30,32,33)}$. Corcuera et al. $^{(34)}$ reported that the level of $\mathrm{AFB}_{1}$ in plasma from rats given a single dose of $0.25 \mathrm{mg} \mathrm{AFB} / \mathrm{kg}$ body weight by oral gavage was $24.8 \mathrm{ng} / \mathrm{ml}$ and $9.5 \mathrm{ng} / \mathrm{ml}$ at $10 \mathrm{~min}$ and $30 \mathrm{~min}$, respectively. Studies on human serum samples mostly have limited sample sizes compared with the current study. In a study performed by Hassan et al. ${ }^{(35)}$, the researchers measured the $\mathrm{AFB}_{1}$ levels in the serum and milk of mothers ( $n$ 50) and serum of infants ( $n$ 50) in Egypt. Twenty-four out of fifty mothers and their infants had been contaminated with $\mathrm{AF}$ with the following mean 
contamination levels: $8 \cdot 9(\mathrm{sD} 4 \cdot 2) \mathrm{ng} / \mathrm{ml}$ (mothers' serum), $1.9(\mathrm{sD} \mathrm{0.6)} \mathrm{ng} / \mathrm{ml}$ (mothers' milk) and $1.8(\mathrm{sD} \mathrm{0.9)} \mathrm{ng} / \mathrm{ml}$ (infants' serum). Tchana et al. ${ }^{(14)}$ showed that $\mathrm{AFB}_{1}$ was present in $63.9 \%$ of the serum samples obtained from patients with liver diseases ( $n$ 36) in Cameroon using HPLC. In another study conducted in the UK using ELISA, AF levels of blood donors ( $n$ 27) were found not to be higher than $20 \mathrm{pg} / \mathrm{ml}$ and it was reported that present UK guideline tolerances for $\mathrm{AF}$ in imported food were effective in limiting human exposure to toxic AF in the UK diet $^{(36)}$. To our knowledge, there is not any study in the literature evaluating the $\mathrm{AF}$ levels in the healthy adult population in Turkey. Our study is the first to assess the blood AF levels in healthy adults along with seasonal and regional variations and the correlations with gender in these particular regions. The highest total AF concentration was found in the summer samples collected from the population living in the Black Sea region. The differences between the regions and seasons were statistically significant. In the Black Sea region, $\mathrm{AFB}_{2}$ levels were found to be higher in females compared with males only in winter. In the Mediterranean region, $\mathrm{AFB}_{1}, \mathrm{AFB}_{2}$ and total AF levels were higher in females $v$. males only in summer. According to the FFQ, Black Sea residents consumed more cereals including corn and corn products, whereas the Mediterranean population consumed more vegetables, fruits and meat as well as locally produced food. We can suggest that the differences in serum AF levels between the regions are due to the consumption of more cereals in the Black Sea region compared with the Mediterranean region whose residents tend to consume more fresh products. In Turkey, it was reported that the concentration of total $\mathrm{AF}$ in wheat samples ranged from 10.4 to $643.5 \mathrm{ng} / \mathrm{kg}$. Sixty per cent of the samples collected in Black Sea and Eastern Anatolia regions of Turkey were found to be positive for total $\mathrm{AF}^{(22)}$. In the study of Giray et $a l .{ }^{(37)}$, the levels of AF and ochratoxin A (OTA) in corn samples grown and consumed in the Black Sea region were reported to be higher than in other regions. The humidity of the Black Sea region can cause favourable conditions for the growth of moulds and production of toxins.

The incidence of AF in foods and feeds is relatively high in tropical and subtropical regions, where climatic conditions provide optimal conditions for the growth of moulds ${ }^{(38,39)}$. Environmental conditions such as temperature, humidity and sunlight can affect the survival of pathogens able to live external to the host, as is the case for mycotoxigenic fungi. Thermo-tolerant species are adapted to warmer climate and, for example, A. flavus may become more problematic than Penicillium verrucosum (i.e. OTA) in temperate Europe ${ }^{(40)}$. In the present study, total AF levels were elevated in the summer period compared with winter for two regions. Overall results suggest that the Turkish population living in these regions is continuously exposed to AF, especially in summer. For the
Black Sea region, the consumption of fruits, legumes, corn and cereal products was found to be higher in summer than in winter. The consumption of fruits was found to be higher in summer than in winter for the Mediterranean region. The climate in both the Black Sea and Mediterranean regions is suitable for the occurrence of mycotoxins due to the hot and humid conditions especially in the summer period. To our knowledge, studies in the literature concerning the changes in AF levels in man according to season are limited. The urinary levels of AF and OTA were determined in children living in Sierra Leone in two seasons and the levels of $\mathrm{AFB}_{1}$ and $\mathrm{AFB}_{2}$ in the dry season were found to be higher compared with the rainy season $^{(41)}$. In 2007, serum AF levels were also measured in children living in the same city and the rate of detection of $\mathrm{AF}$ in the sera of schoolchildren in July was found to be $57 \%{ }^{(42)}$. Wild et al. ${ }^{(43)}$ also reported that in Gambia AF-albumin adduct levels were significantly higher in the dry season than in the wet season among 350 subjects. These results are in agreement with the current study as we also determined higher serum AF levels in summer season for both of the regions.

A number of complicated and expensive approaches have been used to determine AF exposure in human populations, including analysis of AF metabolites and AF-DNA or AF-protein adducts ${ }^{(44-47)}$. In the present study, we determined AF levels in serum samples after the digestion of serum proteins and this provided instantaneous monitoring of AF exposure in the Black Sea and Mediterranean populations.

In our previous study, we determined the OTA levels in the Black Sea and Mediterranean regions using ELISA. The differences between mean values of OTA in the samples collected in summer and winter for each region were statistically significant ${ }^{(48)}$, in agreement with the results obtained in the present study. This shows that in summer mycotoxin production increases because of environmental factors. Besides, in such circumstances, conditions of storage might elevate the mycotoxin contamination in stored food products. Synergistic and additive effects between mycotoxins may also enhance their toxicity. Additional studies on the synergism among mycotoxins must be performed to predict possible in vivo effects of such multi-contaminations.

In Turkey, the incidence of cancer has increased over the years. The most five frequent types of cancer observed in 2002 in Turkey were lung cancer, breast cancer, stomach cancer, skin cancer and bladder cancer, consecutively ${ }^{(49)}$. Liver cancer is the eleventh most common type of cancer in males, affecting $2 \cdot 1$ per 100000 Turkish males, while in females it is the fifteenth most common type of cancer, affecting 1.3 per 100000 Turkish females ${ }^{(50)}$. The rough rate of liver carcinoma in Antalya for males and females was $2 \cdot 5 / 100000$ and $2 \cdot 1 / 100000$, respectively. For the Black Sea region, the rough rate of liver carcinoma in Samsun (a province close to Ordu) for 
males and females was reported to be $2 \cdot 0 / 100000$ and $0 \cdot 5 / 100000$, respectively ${ }^{(50)}$. The exposure to $\mathrm{AF}$ in the population living in these regions may be one of the factors affecting the induction of liver cancer.

Although the present study contributes to the literature by presenting the AF levels of the healthy adult Turkish population, it has some limitations. The number of the subjects used in our study could have been increased. The study could have been conducted on more provinces for it to reflect the whole Turkish population. The analyses of AF contamination of foods consumed in the two provinces could have given more strength to the current study, as this would reflect the relationship between the consumption of AF-contaminated food and blood AF levels.

The food consumed is usually food that families have produced, stored and prepared without any consideration for the risks of AF contamination. Where trade does occur, the least contaminated foods and feeds are exported; this may lead to enhanced exposure of the producers, because the more highly contaminated products are retained at home for consumption by a population that is already at the greatest risk of $\mathrm{AF}$ exposure $^{(51)}$.

\section{Conclusion}

We suggest that novel training programmes on AF contamination should be developed, especially for farmers. New scientific knowledge and improved techniques for harvesting, handling and storage can reduce or eliminate the contamination problem with mycotoxins. Besides, in scientific practice, the importance of overall daily dietary intake of all fungal toxins should not be underestimated. Moreover, a wide variety of foods, particularly cereals, should be monitored routinely for mycotoxins to protect human health and the risk of economic loss.

\section{Acknowledgements}

Sources of funding: This study was funded in part by a grant from Hacettepe University Research Fund (contract grant number: 0401301002). The funder had no role in the design, analysis or writing of this article. Conflict of interest: The authors declare that there are no conflicts of interest. Authors' contributions: S.A., S.S. and P.E. contributed to study concept and design, analysis and interpretation of the data, statistical analysis of the data, and drafting of the manuscript. B.K.G. contributed to study supervision, study concept and design, analysis and interpretation of the data, and drafting of the manuscript. G.S. contributed to study concept and design, and drafting of the manuscript. All authors have seen and approved the final version of the manuscript.

\section{References}

1. International Agency for Research on Cancer (1976) Aflatoxins. In IARC Monographs on the Evaluation of Carcinogenic Risk of Chemicals to Humans. vol. 10: Some Naturally Occurring Substances, pp. 51-72. Lyon: IARC.

2. International Agency for Research on Cancer (1993) Aflatoxins. In: IARC Monographs on the Evaluation of Carcinogenic Risk of Chemicals to Humans. vol. 56: Some Naturally Occurring Substances: Food Items and Constituents, Heterocyclic Aromatic Amines, and Mycotoxins, pp. 245-395. Lyon: IARC.

3. International Agency for Research on Cancer (2002) Aflatoxins. In IARC Monographs on the Evaluation of Carcinogenic Risks to Humans. vol. 82: Traditional Herbal Medicines, Some Mycotoxins, Naphthalene and Styrene, pp. 171-366. Lyon: IARC.

4. National Toxicology Program (2011) Aflatoxins. In Report on Carcinogens, Twelfth Edition 2011. Research Triangle Park, NC: US Department of Health and Human Services, Public Health Service, National Toxicology Program; available at http://ntp.niehs.nih.gov/ntp/roc/ twelfth/roc12.pdf

5. International Agency for Research on Cancer (1987) Aflatoxins. In IARC Monographs on the Evaluation of Carcinogenic Risk of Chemicals to Humans. suppl. 7: Overall Evaluations of Carcinogenicity: An Updating of IARC Monographs Volumes 1 to 42, pp. 83-87. Lyon: IARC.

6. Garner RC \& Martin CN (1979) Fungal toxins, aflatoxins and nucleic acids. In Chemical Carcinogens and DNA, pp. 187-225 [PL Grover, editor]. Boca Raton, FL: CRC Press.

7. Kotsonis FN \& Burdock GA (2008) Food toxicology. In Casarett and Doull's Toxicology: The Basic Science of Poisons, pp. 1191-1236 [CD Klassen, editor]. New York: McGraw-Hill Companies Inc.

8. Williams JH, Phillips TD, Jolly PE et al. (2004) Human aflatoxicosis in developing countries: a review of toxicology, exposure, potential health consequences, and interventions. Am J Clin Nutr 80, 1106-1122.

9. Bushby LA \& Wogan GN (1981) Aflatoxins. In Mycotoxins and N-Nitroso Compounds: Environmental Risks, pp. 3-29 [RC Shank, editor]. Boca Raton, FL: CRC Press.

10. Dragan YP \& Pitot HC (1993) Aflatoxin carcinogenesis in the context of the multistage nature of cancer. In The Toxicology of Aflatoxins: Human Health, Veterinary, and Agricultural Significance, pp. 179-206 [DL Eaton and JD Groopman, editors]. London: Academic Press.

11. Chen CJ, Wang LY, Lu SN et al. (1996) Elevated aflatoxin exposure and risk of hepatocellular carcinoma. Hepatology 24, 38-42.

12. London WT, Evans AA, McGlynn K et al. (1995) Viral, host and environmental risk factors for hepatocellular carcinoma: a prospective study in Haimen city, China. Intervirology $\mathbf{3 8}$, $155-161$.

13. Lopez C, Ramos L, Bulacio L et al. (2002) Aflatoxin $B_{1}$ content in patients with hepatic diseases. Medicina (B Aires) 62, 313-316.

14. Tchana AN, Moundipa PF \& Tchouanguep FM (2010) Contamination in food and body fluids in relation to malnutrition and cancer status in Cameroon. Int J Environ Res Public Health 7, 178-188.

15. Bushby WF \& Wogan GN (1979) Food-borne mycotoxins and alimentary mycotoxicoses. In Food-Borne Infections and Intoxications, pp. 519-610 [H Riemann and FL Bryan, editors]. New York: Academic Press.

16. Wang JS \& Tang L (2005) Epidemiology of aflatoxin exposure and human liver cancer. In Aflatoxin and Food Safety, pp. 195-211 [HK Abbas, editor]. Boca Raton, FL: CRC Press. 
17. Candlish AAG, Pearson SM, Aidoo KE et al. (2001) A survey of ethnic foods for microbial quality and aflatoxin content. Food Addit Contam 18, 129-136.

18. Turkish Food Codex (2002) Notification on determination of detection limits of certain contaminants in foods. Official Gazette 23.09.2002, no. 24885. Ankara: Prime Ministery Press (in Turkish); available at http://www.istanbulsaglik.gov.tr/ w/mev/mev_tebl/tebl_temel_saglik/belirli_bulasanlar.pdf

19. Camlibel L (1995) IGEME Research and Development Presidency, pp. 1-23. Ankara: Agricultural Administration (in Turkish).

20. Baydar T, Erkekoglu P, Sipahi $\mathrm{H}$ et al. (2007) Aflatoxin $\mathrm{B}_{1}$, $\mathrm{M}_{1}$ and ochratoxin A levels in infant formulae and baby foods marketed in Ankara, Turkey. J Food Drug Anal 15, 89-92.

21. Duru S \& Sahin G (1979) Aflatoxin $B_{1}$ in flours. Mikrobiyol Bul 13, 371-376.

22. Giray B, Girgin G, Engin AB et al. (2007) Aflatoxin levels in wheat samples consumed in some regions of Turkey. Food Control 18, 23-29.

23. Nizam F \& Oguz H (2001) Occurrence of aflatoxins in layer feed and corn samples in Konya province, Konya. Food Addit Contam 20, 654-658.

24. Omurtag GZ, Atak G, Keskin G et al. (2002) HPLC assay for aflatoxins in dried red peppers and feedstuffs in Turkey. Acta Pharmaceut Turc 44, 11-22.

25. Simsek SE \& Bozkurt N (1992) Investigation of aflatoxin in flour and breads which are collected from bakeries. Turk Hij Tecr Biyol Derg 49, 139-147.

26. AOAC International (1995) Natural toxins. In Official Methods of Analysis of AOAC International, section 990.33 [P Cunniff, editor]. Gaithersburg, MD: AOAC International.

27. World Health Organization (2000) The problem of overweight and obesity. In Obesity: Preventing and Managing the Global Epidemic. WHO Technical Report Series no. 894, pp. 6-13. Geneva: WHO Press.

28. Aldini G, Vistoli G, Regazzoni L et al. (2008) Albumin is the main nucleophilic target of human plasma: a protective role against pro-atherogenic electrophilic reactive carbonyl species? Chem Res Toxicol 21, 824-835.

29. Wild CP, Yin F, Turner PC et al. (2000) Environmental and genetic determinants of aflatoxin-albumin adducts in the Gambia. Int J Cancer 86, 1-7.

30. Nelson DB, Kimbrough R, Landrigan PS et al. (1980) Aflatoxin and Reye's syndrome: a case study. Pediatrics 66, 865-869.

31. US Environmental Protection Agency (2012) 40 CFR Part 136. Guidelines establishing test procedures for the analysis of pollutants. http://www.epa.gov/region9/qa/ pdfs/40cfr136_03.pdf (accessed January 2013).

32. Siraj MY, Hayes AW, Unger PD et al. (1981) Analysis of aflatoxin $\mathrm{B}_{1}$ in human tissues with high-pressure liquid chromatography. Toxicol Appl Pharmacol 58, 422-430.

33. Wray BB \& Hayes AW (1980) Aflatoxin $B_{1}$ in the serum of a patient with primary hepatic carcinoma. Environ Res 22, 400-403.

34. Corcuera LA, Vettorazzi A, Arbillaga L et al. (2012) An approach to the toxicity and toxicokinetics of aflatoxin $B_{1}$ and ochratoxin A after simultaneous oral administration to fasted F344 rats. Food Chem Toxicol 50, 3440-3446.

35. Hassan AM, Sheashaa HA, Abdel Fatah MF et al. (2006) Does aflatoxin as an environmental mycotoxin adversely affect the renal and hepatic functions of Egyptian lactating mothers and their infants? A preliminary report. Int Urol Nephrol 38, 339-342.

36. Wilkinson AP, Denning DW \& Morgan MR (1988) Analysis of UK sera for aflatoxin by enzyme-linked immunosorbent assay. Hum Toxicol 7, 353-356.

37. Giray B, Atasayar S \& Sahin G (2009) Determination of ochratoxin A and total aflatoxin levels in corn samples in some regions of Turkey by enzyme-linked immunosorbent assay. Mycotoxin Res 25, 113-116.

38. Rustom IYS (1997) Aflatoxin in food and feed: occurrence, legislation and inactivation by physical methods. Food Chem 59, 57-67.

39. Shearer JF, Sweets LE, Baker NK et al. (1992) A study of Aspergillus flavus/parasiticus in Iowa crop fields: 1988-1990. Plant Dis 76, 19-22.

40. Paterson RRM \& Lima N (2010) How will climate change affect mycotoxins in food? Food Res Int 43, 1902-1904.

41. Jonsyn-Ellis FE (2001) Seasonal variation in exposure frequency and concentration levels of aflatoxins and ochratoxins in urine samples of boys and girls. Mycopathologia 152, 35-40.

42. Jonsyn-Ellis FE (2007) Aflatoxins and ochratoxins in serum samples of school children. J Nutr Environ Med 16, 52-58.

43. Wild CP, Hasegawa R, Barraud L et al. (1996) Aflatoxinalbumin adducts: a basis for comparative carcinogenesis between animals and man. Cancer Epidemiol Biomarkers Prev 5, 179-189.

44. Chen $\mathrm{CH}$, Wang $\mathrm{MH}$, Wang $\mathrm{JH}$ et al. (2007) Aflatoxin exposure and hepatitis $\mathrm{C}$ virus in advanced liver disease in a hepatitis $\mathrm{C}$ virus endemic area in Taiwan. Am J Trop Med Hyg 77, 747-752.

45. Johnson NM, Qian G, Xu L et al. (2010) Aflatoxin and PAH exposure biomarkers in a US population with a high incidence of hepatocellular carcinoma. Sci Total Environ 408, 6027-6031.

46. Leong YH, Rosma A, Latiff AA et al. (2012) Associations of serum aflatoxin B1-lysine adduct level with sociodemographic factors and aflatoxins intake from nuts and related nut products in Malaysia. Int J Hyg Environ Health 215, 368-372.

47. Wild CP, Fortuin M, Donato F et al. (1993) Aflatoxin, liver enzymes, and hepatitis B virus infection in Gambian children. Cancer Epidemiol Biomarkers Prev 2, 555-556.

48. Erkekoğlu P, Sabuncuoğlu S, Aydin S et al. (2010) Determination of seasonal variations in serum ochratoxin A levels in healthy population living in some regions of Turkey by enzyme-linked immunosorbent assay. Toxicon 55, 507-513.

49. Yardim N \& Mollahaliloğlu S (2006) The situation of cancer in Turkey and evaluation of its coherence with international indicators. In Cancer Control in Turkey, pp. 111-128 [M Tuncer, editor]. Ankara: Refik Saydam Hygiene Center, Directorate of Hygiene School, Ministry of Health (in Turkish); available at www.ukdk.org/pdf/kitap/ en/8.pdf

50. Eser YS (2010) Cancer registration and cancer registration centers. In Cancer Incidence in Turkey, pp. 15-34 [M Tuncer, editor]. Ankara: Koza Press; available at http://www.calameo. com/books/000713529b152e4a796d3

51. Henry SH, Bosch FX, Troxell TC et al. (1999) Reducing liver cancer - global control of aflatoxin. Science 286, $2453-2454$. 